\title{
Ecotoxicity of binary mixtures of ILs and inorganic salts of electrochemical interest
}

\author{
Juan José Parajó ${ }^{1,2} \cdot$ Pablo Vallet $^{1} \cdot$ Luis Miguel Varela $^{1} \cdot$ María Villanueva $^{1} \cdot$ Josefa Salgado $^{1}$ (i)
}

Received: 12 May 2021 / Accepted: 9 November 2021 / Published online: 27 November 2021

(c) The Author(s) 2021

\begin{abstract}
The applicability of ionic liquids (ILs) has increased over the last years, and even new opportunities are becoming a reality, i.e. mixtures of pure IL and inorganic salt as electrolytes for smart electrochemical devices, yet the effects on the environment are almost unknown. In this work, the ecotoxicity of two pure protic ILs (Ethylammonium nitrate and Ethylimidazolium nitrate) and two pure aprotic ILs (butylmethylpyrrolidinium bis(trifluoromethylsulfonyl)imide and butyldimethylimidazolium bis(trifluoromethylsulfonyl)imide) and that of their binary mixtures with inorganic salts with common cation was tested towards changes in the bioluminescence of the bacteria Aliivibrio fischeri, using the Microtox® standard toxicity test. $\mathrm{EC}_{50}$ of these mixtures was determined over three standard periods of time and compared with the corresponding values to pure ILs. Results indicate that the aprotic ILs are more toxic than protic and that aromatic are more toxic than non-aromatic. The addition of inorganic mono $\left(\mathrm{LiNO}_{3}\right)$, di $\left(\mathrm{Ca}\left(\mathrm{NO}_{3}\right)_{2} \cdot 4 \mathrm{H}_{2} \mathrm{O}, \mathrm{Mg}\left(\mathrm{NO}_{3}\right)_{2} \cdot 6 \mathrm{H}_{2} \mathrm{O}\right)$ and trivalent $\left(\mathrm{Al}\left(\mathrm{NO}_{3}\right)_{3} \cdot 9 \mathrm{H}_{2} \mathrm{O}\right)$ salts in binary mixtures with EAN was analysed first. The latter was found to induce an important increase in toxicity. Finally, mixtures of IL-inorganic lithium salt $\left(\mathrm{LiNO}_{3}\right.$, for the protic ILs and LiTFSI for the aprotic ILs) toxicity was also studied, which showed toxicity levels strongly dependent on the IL of the mixture.
\end{abstract}

Keywords Ionic liquids $\cdot$ Ecotoxicity $\cdot$ Smart electrolyte $\cdot$ Microtox $^{\circledR}$

\section{Introduction}

As is well known, ionic liquids (ILs) are compounds formed entirely by ions which have low melting points. The number of applications seems to be endless since they have still not been fully studied as pure, in mixtures with other compounds or with active pharmaceutical ingredients (APIs) incorporated in their structures besides many other possibilities (Rodríguez and Brennecke 2006; Rana et al. 2010; Silva et al. 2016; Toledo-Hijo et al. 2016; Salgado et al. 2019).

Responsible Editor: Bruno Nunes

Josefa Salgado

j.salgado.carballo@usc.es

1 NAFOMAT Group, Departamentos de Física Aplicada y Física de Partículas, Universidade de Santiago de Compostela, 15782 Santiago de Compostela, Spain

2 Departamento de Química e Bioquímica, CIQUP - Centro de Investigação em Química da Universidade do Porto, Universidade do Porto, P-4169-007 Porto, Portugal
The main characteristic of ILs is the low vapour pressure, which means non-volatility, and therefore, they were, at first, used to substitute traditional industrial solvents, most of which are volatile organic compounds (VOCs), one of the most sources of environmental pollution in the chemical industry (Rogers and Seddon 2003). This led to them being labelled green solvents, although recent studies concluded that the toxicity of some ILs is similar, or even higher, than traditional solvents (Studzinska and Buszewski 2009; Santos et al. 2014).

Aside from non-volatility, other characteristic properties of ILs include high thermal and chemical stability, high viscosity, solubility in water and other solvents, a wide electrochemical window and especially tuneability (Yasuda et al. 2013). All these characteristics make ILs good candidates to be used in high-temperature applications such as lubrication (Otero et al. 2014), desulfurization of fuels (Gutiérrez et al. 2018), batteries (Menne et al. 2013; Balducci 2017; Wang et al. 2020), fuel cells (Nakamoto and Watanabe 2007), fluids in refrigeration systems (Sánchez et al. 2016; Moreno et al. 2018) and APIs (Shamshina and Rogers 2020). 
ILs can be divided into two different subclasses depending on their structural characteristics: protic (PILs) and aprotic (AILs) ionic liquids. PILs are formed by the proton transfer from acid to base. Hence, they consist of protondonor and -acceptor sites, which are responsible for building extended three-dimensional hydrogen bond networks, as in the case of water. AILs are also mainly based on bulky organic cations (i.e. pyrrolidinium, imidazolium) with long alkyl chain substituents and on a huge variety of anions (i.e. TFSI, FAP, halides). In recent years, significant growth in the structure-property relationships of ILs has been achieved with a better understanding of the intermolecular forces (Salgado et al. 2013; Sánchez et al. 2019).

One of the most cited applications in the literature is electrochemistry. Inorganic salt-doped ionic liquids are highly promising electrolyte media compatible with inorganic and organic electrodes for batteries, supercapacitors and other electrochemical storage devices. Lithium salts are those most used for doping ILs (Menne et al. 2013; Balducci 2017), finding high Li transport numbers and improving ionic conductivity. Moreover, divalent and trivalent salts as well as IL mixtures also showed promising results, improving some properties that further extend the range of application of these compounds (Yang et al. 2020). Salgado et al. (2019) have stated that melting and glass transition temperatures decrease with increasing salt concentration, whilst thermal stability is not significantly affected. Kim et al. (2011) have studied the mixture n-butyl-n-methylpyrrolidinium TFSI with Li TFSI salt, showing a slight decrease in ionic conductivity when salt concentration increases. These papers also comment on the applicability in refrigeration besides the most traditional applications in electrochemistry and other uses.

In addition to good physicochemical properties of these compounds, current European Union environmental legislation, including REACH (Regulation concerning registration, Evaluation, Authorization and Restriction of Chemicals) (Commission 2006), requires the use of safety materials, highlighting the principles of Green Chemistry as prevention, economy, less hazardous chemical synthesis, efficient use of energy, use of renewable raw and biodegradable materials, monitoring of real-time technological processes and provision of an adequate level of chemical safety.

Therefore, it is urgent to establish evaluation procedures to estimate the toxicity of ILs that can readily provide the needed information and reduce costs. Aliivibrio fischeri (A. fischeri) is a well-known marine luminescent bacterium with a short reproductive cycle, and whose toxicity inference may be extrapolated to a wide variety of aquatic organisms. Thus, it can be effectively applied for toxicological risk assessment (Ventura et al. 2013; Parajó et al. 2019).

It is generally accepted that the structure of ILs has an important influence on the physical and chemical properties as well as in toxicity, although further studies need to be performed. Consequently, the specific choice of cation and anion has an important influence on the ecotoxicity of ionic liquids. It is well known that ILs with aromatic cations are more toxic than non-aromatic ones, mainly due to their water solubility (Ventura et al. 2013). Moreover, imidazolium- and pyridinium-based ILs with a specific anion show the highest harmful effects among other cations, with $\mathrm{EC}_{50}$ of 130 $\mathrm{mg} / \mathrm{L}$ for the 1-butyl-3-methylpyridinium bromide and 5525 $\mathrm{mg} / \mathrm{L}$ for 1-butyl-1-methylpyrrolidinium bromide as Ibrahim et al. (2017) highlighted in their work. These researchers also underline that the alkyl chain length also has a strong influence on ecotoxicity, as well as in other thermophysical properties such as density and viscosity. As a consequence, $\mathrm{EC}_{50}$ is reduced by almost four orders of magnitude, from $3234 \mathrm{mg} / \mathrm{L}$ (relatively harmless) for 1-ethyl-3-methylimidazolium chloride to $0.58 \mathrm{mg} / \mathrm{L}$ for 1-hexadecyl-3-methylimidazolium chloride (highly toxic, according to Passino and Smith classification (Passino and Smith 1987) ). With regard to the anion, in spite of its undoubted influence, the effects depend on the cation moiety; for example, for the cation $[\mathrm{Emim}]^{+}$, the $\mathrm{EC}_{50}$ are $9213 \mathrm{mg} / \mathrm{L}$ and $1631 \mathrm{mg} / \mathrm{L}$ for the $[\mathrm{Cl}]^{-}$and $[\mathrm{TFSI}]^{-}$anions, respectively. Nevertheless, for the cation $\left[\mathrm{C}_{8} \mathrm{mim}\right]^{+}$, the corresponding values are 2.36 $\mathrm{mg} / \mathrm{L}$ for chloride and $6.44 \mathrm{mg} / \mathrm{L}$ for [TFSI] $^{-}$(moderately toxic), which shows that the trend followed for the anions can change with the alkyl chain length.

Furthermore, several prediction models have been used for estimating the toxicity of ILs towards different endpoints, most of them through the QSAR (quantitative structure-activity relationship) technique (Luis et al. 2010; Ibrahim et al. 2017). A recent paper (Kang et al. 2020) developed an interesting method for predicting the toxicity of ILs from the electrostatic potential surface area of separate cation and anion of 142 ILs using a learning machine algorithm, obtaining excellent results. Nevertheless, in the most recent literature, toxicity predictive methods are gaining ground on experimental methods, which are time-consuming and more expensive. There is still a significant gap in the knowledge of the harmful effects of ILs, both pure and in mixtures with other solvents or salts.

With the aim of contributing to the enlargement of the database of toxic effects of ILs and the consequent improvement of the knowledge of the relationship between toxicity and structure, the ecotoxicity of two protic ILs (ethylammonium nitrate (EAN) and ethylimidazolium nitrate (EIm $\mathrm{NO}_{3}$ )) and two aprotic ILs (butylmethylpyrrolidinium bis(trifluoromethylsulfonyl)imide $\left(\mathrm{C}_{4} \mathrm{C}_{1}\right.$ pyrr TFSI) and butyldimethylimidazolium bis(trifluoromethylsulfonyl) imide $\left(\mathrm{C}_{4} \mathrm{C}_{1} \mathrm{C}_{1} \mathrm{Im}\right.$ TFSI)) was tested towards changes on the bioluminescence of the bacteria $A$. fischeri, using the Microtox ${ }^{\circledR}$ standard toxicity test. Additionally, changes in the ecotoxicity as a consequence of the doping of these 
ILs with different salts with electrochemical interest were also determined. Firstly, the doping of the corresponding lithium salt $\left(\mathrm{LiNO}_{3}\right.$, for the protic ILs and LiTFSI for the aprotic IL) was evaluated, and finally, effects of mono $\left(\mathrm{LiNO}_{3}\right)$, di $\left(\mathrm{Ca}\left(\mathrm{NO}_{3}\right)_{2} \cdot 4 \mathrm{H}_{2} \mathrm{O}, \mathrm{Mg}\left(\mathrm{NO}_{3}\right)_{2} \cdot 6 \mathrm{H}_{2} \mathrm{O}\right)$ and trivalent $\left(\mathrm{Al}\left(\mathrm{NO}_{3}\right)_{3} \cdot 9 \mathrm{H}_{2} \mathrm{O}\right)$ salts were also estimated for EAN. The effective concentration $\left(\mathrm{EC}_{50}\right)$ of these mixtures was determined over three standard periods of time, namely 5 $\mathrm{min}, 15 \mathrm{~min}$ and $30 \mathrm{~min}$, and compared with the corresponding values to pure ILs.

\section{Materials and methods}

\section{Chemicals}

The main characteristics of the four selected ILs (EAN, EIm $\mathrm{NO}_{3}, \mathrm{C}_{4} \mathrm{C}_{1}$ pyrr TFSI and $\mathrm{C}_{4} \mathrm{C}_{1} \mathrm{C}_{1}$ Im TFSI) and the inorganic salt $\left(\mathrm{LiNO}_{3}, \mathrm{Ca}\left(\mathrm{NO}_{3}\right)_{2} \cdot 4 \mathrm{H}_{2} \mathrm{O}, \mathrm{Mg}\left(\mathrm{NO}_{3}\right)_{2} \cdot 6 \mathrm{H}_{2} \mathrm{O}\right.$, $\mathrm{Al}\left(\mathrm{NO}_{3}\right)_{3} \cdot 9 \mathrm{H}_{2} \mathrm{O}$ and LiTFSI) are shown in Table 1. Ionic liquids were dried in a high vacuum under constant stirring for at least $24 \mathrm{~h}$, and the water content, measured by Karl Fischer titration, was below 100 ppm for all liquids. Calcium, magnesium and aluminium nitrate are hydrated salts with four, six and nine water molecules, respectively, and their purity was analysed by EDTA titration. Saturated mixtures of these ILs with lithium salt with common anion were prepared, and salt concentration, in molality and molar fraction, and mixture molecular mass are shown in Table 2. Similarly, saturated mixtures of EAN with lithium, calcium, magnesium and aluminium nitrate salts were also prepared. Saturated concentrations and the molecular mass of the mixtures are summarised in Table 3. All these mixtures were obtained by mixing components, ionic liquid and salt as supplied, with the help of an ultrasound bath and a magnetic stirrer for at least $48 \mathrm{~h}$. The saturated concentrations were determined by increasing molality in intervals of $0.5 \mathrm{~mol} / \mathrm{kg}$ until precipitation is observed at room temperature (Salgado et al. 2019).

\section{Experimental section}

Acute toxicity was assessed by determining the luminescence inhibition of the rod-shaped Gram-negative marine bacteria Aliivibrio fischeri (A. fischeri), that bioluminesces through a population-dependent mechanism called quorum sensing sensitive to a wide variety of toxic substances (Ibrahim et al. 2017). Standard Microtox ${ }^{\circledR}$ liquid
Table 1 Chemical structure, identification number, molecular mass and purity of ILs and salts

\begin{tabular}{|c|c|c|c|}
\hline $\begin{array}{c}\text { Name } \\
\text { Molecular Mass (g/mol) }\end{array}$ & $\begin{array}{l}\text { Abbreviation } \\
\text { CAS Number }\end{array}$ & Chemical Structure & $\begin{array}{c}\text { Purity } \\
\text { Provenance }\end{array}$ \\
\hline $\begin{array}{l}\text { Ethylammonium Nitrate } \\
108.10\end{array}$ & $\begin{array}{c}\text { EAN } \\
22113-86-6\end{array}$ & & $\begin{array}{c}>0.97 \\
\text { Iolitec }\end{array}$ \\
\hline $\begin{array}{l}\text { Ethylimidazolium nitrate } \\
159.14\end{array}$ & $\begin{array}{c}\mathrm{EIm} \mathrm{NO}_{3} \\
501693-38-5\end{array}$ & & $\begin{array}{l}>0.98 \\
\text { Iolitec }\end{array}$ \\
\hline $\begin{array}{c}\text { Butylmethylpyrrolidinium } \\
\text { bis(trifluoromethylsulfonyl)imide } \\
422.41\end{array}$ & $\begin{array}{c}\mathrm{C}_{4} \mathrm{C}_{1} \text { pyrr TFSI } \\
223437-11-4\end{array}$ & & $\begin{array}{l}>0.99 \\
\text { IoLiTec }\end{array}$ \\
\hline $\begin{array}{c}\text { Butylmethylmethylimidazolium } \\
\text { bis(trifluoromethylsulfonyl)imide } \\
433.39 \\
\end{array}$ & $\begin{array}{c}\mathrm{C}_{4} \mathrm{C}_{1} \mathrm{C}_{1} \text { Im TFSI } \\
350493-08-2\end{array}$ & & $\begin{array}{l}>0.99 \\
\text { IoLiTec }\end{array}$ \\
\hline $\begin{array}{l}\text { Lithium Nitrate } \\
\quad 68.95\end{array}$ & $\begin{array}{c}\mathrm{LiNO}_{3} \\
7790-69-4\end{array}$ & $\mathrm{Li}^{+}$ & $\begin{array}{l}>0.999 \\
\text { Merck }\end{array}$ \\
\hline $\begin{array}{l}\text { Calcium Nitrate } \\
\text { Tetrahydrate } \\
236.088\end{array}$ & $\begin{array}{c}\mathrm{Ca}\left(\mathrm{NO}_{3}\right)_{2} \cdot 4 \mathrm{H}_{2} \mathrm{O} \\
13477-34-4\end{array}$ & $\mathrm{Ca}^{+2}$ & $\begin{array}{l}>0.999 \\
\text { Merck }\end{array}$ \\
\hline $\begin{array}{l}\text { Magnesium Nitrate } \\
\text { Hexahydrate } \\
256.3\end{array}$ & $\begin{array}{c}\mathrm{Mg}\left(\mathrm{NO}_{3}\right)_{2} \cdot 6 \mathrm{H}_{2} \mathrm{O} \\
13446-18-9\end{array}$ & $\mathrm{Mg}^{+2}$ & $\begin{array}{l}>0.999 \\
\text { Merck }\end{array}$ \\
\hline $\begin{array}{c}\text { Aluminium Nitrate } \\
\text { Nonahydrate } \\
374.996\end{array}$ & $\begin{array}{c}\mathrm{Al}\left(\mathrm{NO}_{3}\right)_{3} \cdot 9 \mathrm{H}_{2} \mathrm{O} \\
7784-27-2\end{array}$ & $\mathrm{Al}^{+3}$ & $\begin{array}{l}>0.999 \\
\text { Merck }\end{array}$ \\
\hline $\begin{array}{c}\text { Lithium } \\
\text { bis(trifluoromethylsulfonyl)imide } \\
287.09\end{array}$ & $\begin{array}{c}\text { LiTFSI } \\
90076-65-6\end{array}$ & & $\begin{array}{c}>0.99 \\
\text { Acros } \\
\text { organics }\end{array}$ \\
\hline
\end{tabular}


Table 2 Lithium salt saturation concentration (molality and molar fraction) in mixtures IL+salt and molecular mass $\left(\mathrm{M}_{\mathrm{m}}\right)$ for the mixtures

\begin{tabular}{lllll}
\hline Mixture & $\mathrm{EAN}+\mathrm{LiNO}_{3}$ & $\begin{array}{l}\mathrm{C}_{4} \mathrm{C}_{1} \text { pyrr TFSI }+ \\
\mathrm{LiTFSI}\end{array}$ & $\mathrm{EIm} \mathrm{NO}_{3}+\mathrm{LiNO}_{3}$ & $\begin{array}{l}\mathrm{C}_{4} \mathrm{C}_{1} \mathrm{C}_{1} \mathrm{ImTFSI}_{2} \\
+\mathrm{LiTFSI}\end{array}$ \\
\hline Molality (mol/l) & 2.000 & 1.500 & 2.000 & 1.000 \\
$x_{\text {salt }}$ & 0.178 & 0.388 & 0.241 & 0.399 \\
$\mathrm{M}_{\mathrm{m}}(\mathrm{g} / \mathrm{mol})$ & 123.01 & 604.31 & 181.08 & 204.83 \\
\hline
\end{tabular}

\begin{tabular}{lllll}
\hline Mixture & $\mathrm{EAN}+\mathrm{LiNO}_{3}$ & $\begin{array}{l}\mathrm{EAN}+ \\
\mathrm{Ca}\left(\mathrm{NO}_{3}\right)_{2} \cdot 4 \mathrm{H}_{2} \mathrm{O}\end{array}$ & $\begin{array}{l}\mathrm{EAN}+ \\
\mathrm{Mg}\left(\mathrm{NO}_{3}\right)_{2} \cdot 6 \mathrm{H}_{2} \mathrm{O}\end{array}$ & $\begin{array}{l}\mathrm{EAN}+ \\
\mathrm{Al}_{\left(\mathrm{NO}_{3}\right)_{3}} \cdot 9 \mathrm{H}_{2} \mathrm{O}\end{array}$ \\
\hline Molality (mol/l) & 2.000 & 1.000 & 2.000 & 2.000 \\
$x_{\text {salt }}$ & 0.178 & 0.270 & 0.446 & 0.540 \\
$\mathrm{M}_{\mathrm{m}}(\mathrm{g} / \mathrm{mol})$ & 123.01 & 133.62 & 163.51 & 189.17 \\
\hline
\end{tabular}

Table 3 Salt saturation concentration (molality and molar fraction) in mixtures $\mathrm{EAN}+$ salt and molecular mass $\left(\mathrm{M}_{\mathrm{m}}\right)$ for the mixtures

phase assays (M500 Analyser - modern water) was used for this proposal. This method is currently one of the most widespread and well-known toxicological bioassays due to its simplicity and quick measurements (Johnson 2005; Chang et al. 2013; Ventura et al. 2014; Parajó et al. 2019). After exposing the bacteria at $15^{\circ} \mathrm{C}$ to each different IL or IL+salt aqueous solution (from 0 to $81.9 \%$ ), the light output at $5 \mathrm{~min}, 15 \mathrm{~min}$ and $30 \mathrm{~min}$ was measured and compared with a blank control sample. The concentration of the sample $(\mathrm{mg} / \mathrm{L})$ which produces a $50 \%$, $20 \%$ and $10 \%$ luminescence inhibition after exposure at the three selected times ( $5 \mathrm{~min}, 15 \mathrm{~min}$ and $30 \mathrm{~min}$ ) is designated as effective concentration $\left(\mathrm{EC}_{50}, \mathrm{EC}_{20}\right.$ and $\mathrm{EC}_{10}$, respectively) and is calculated, together with the corresponding $95 \%$ confidence intervals, through nonlinear regression, using the least-squares method to fit the data to the logistic equation (Parajó et al. 2019). The drop in bioluminescence whilst increasing the concentration of the sample constitutes an integrated measure of the physiological impairment of the bacteria, hence demonstrating the toxic effect of the studied compound (Ventura et al. 2014).

With the aim to clarify the methodology, Table 4 indicates the initial concentrations $(\mathrm{mg} / \mathrm{L})$ of the mixture stock solutions prepared for the Microtox ${ }^{\circledR}$ measurements.

In this work, two classifications were used to distinguish the toxicity of the compounds. The first one is the widely used and proposed by Passino and Smith (1987) based on the values of $\mathrm{EC}_{50}$ at $30 \mathrm{~min}: \mathrm{EC}_{50}>1000 \mathrm{mg} / \mathrm{L}$, relatively harmless; $100 \mathrm{mg} / \mathrm{L}<\mathrm{EC}_{50}<1000 \mathrm{mg} / \mathrm{L}$, practically harmless; $1 \mathrm{mg} / \mathrm{L}<\mathrm{EC}_{50}<100 \mathrm{mg} / \mathrm{L}$, toxic; 0.1 $\mathrm{mg} / \mathrm{L}<\mathrm{EC}_{50}<1 \mathrm{mg} / \mathrm{L}$, highly toxic; and $0.01 \mathrm{mg} / \mathrm{L}<$ $\mathrm{EC}_{50}<0.1 \mathrm{mg} / \mathrm{L}$, extremely toxic.

The other classification is based on the studies of Chang et al. (2013), who used the concept of toxicity units, calculated by
Table 4 Initial concentrations ( $\mathrm{mg} / \mathrm{L}$ ) of pure ILs and binary mixture stock solutions prepared for the Microtox ${ }^{\circledR}$ measurements

\begin{tabular}{|c|c|}
\hline Compound & Concentration $/ \mathrm{mg} \cdot \mathrm{L}^{-1}$ \\
\hline EAN & $44.461 \cdot 10^{3}$ \\
\hline $\mathrm{EAN}+\mathrm{LiNO}_{3} 2 \mathrm{~m}$ & $50.850 \cdot 10^{3}$ \\
\hline $\mathrm{EAN}+\mathrm{Ca}\left(\mathrm{NO}_{3}\right)_{2} 1 \mathrm{~m}$ & $43.346 \cdot 10^{3}$ \\
\hline $\mathrm{EAN}+\mathrm{Mg}\left(\mathrm{NO}_{3}\right)_{2} 2 \mathrm{~m}$ & $36.893 \cdot 10^{3}$ \\
\hline $\mathrm{EAN}+\mathrm{Al}\left(\mathrm{NO}_{3}\right)_{3} 2 \mathrm{~m}$ & $3.340 \cdot 10^{3}$ \\
\hline $\mathrm{C}_{4} \mathrm{C}_{1}$ pyrr TFSI & $5.394 \cdot 10^{3}$ \\
\hline $\mathrm{C}_{4} \mathrm{C}_{1}$ pyrr TFSI + LiTFSI $1.5 \mathrm{~m}$ & $5.929 \cdot 10^{3}$ \\
\hline $\mathrm{EIm} \mathrm{NO}_{3}$ & $61.172 \cdot 10^{3}$ \\
\hline $\mathrm{EIm} \mathrm{NO}_{3}+\mathrm{LiNO}_{3} 2 \mathrm{~m}$ & $15.915 \cdot 10^{3}$ \\
\hline $\mathrm{C}_{4} \mathrm{C}_{1} \mathrm{C}_{1} \mathrm{Im}$ TFSI & $14.590 \cdot 10^{3}$ \\
\hline $\mathrm{C}_{4} \mathrm{C}_{1} \mathrm{C}_{1} \mathrm{Im}$ TFSI + LiTFSI $1 \mathrm{~m}$ & $2.689 \cdot 10^{3}$ \\
\hline
\end{tabular}

$T U=\frac{100}{E C_{50}}$

$\mathrm{EC}_{50}$ (in $\mathrm{mg} / \mathrm{L}$ ) was measured after 15 min of exposition. Thus, the toxicity steps are defined as follows: $\mathrm{TU}<1$, nontoxic; $1<\mathrm{TU}<10$, toxic; $10<\mathrm{TU}<100$, very toxic; and $\mathrm{TU}>100$, extremely toxic.

\section{Results and discussion Toxicity of pure ILs}

A set of ecotoxicity parameters obtained $\left(\mathrm{EC}_{10}, \mathrm{EC}_{20}\right.$ and $\mathrm{EC}_{50}$ ) for four ILs, two protic and two aprotic, towards the toxicity endpoint of bioluminescence of the bacteria $A$. fischeri is reported in this work. Although the most used parameter is $\mathrm{EC}_{50}$, which is the concentration for a $50 \%$ of reduction in the luminescence of the bacteria, $\mathrm{EC}_{10}$ and $\mathrm{EC}_{20}$ (concentrations to reduce $10 \%$ and $20 \%$ regarding the initial luminescence, respectively) also provide intermediate toxicity references. Hence, a more complete ecotoxicological characterisation of these compounds is included. 
Furthermore, $\mathrm{EC}_{10}$ and $\mathrm{EC}_{20}$ are starting points for the estimation of the lowest observed effect concentration. $\mathrm{EC}_{10}$ is particularly useful as a reliable parameter of the effects independent of concentration or for the lowest environmental risk compounds (Ventura et al. 2014). Tables 5, 6 and 7 present the values of $\mathrm{EC}_{10}, \mathrm{EC}_{20}$ and $\mathrm{EC}_{50}$, respectively, of pure ILs for $5 \mathrm{~min}, 15 \mathrm{~min}$ and $30 \mathrm{~min}$ of exposition.

Figure 1 shows the behaviour of inhibition of the bioluminescence of Aliivibrio fischeri bacteria versus the concentration of the four pure ionic liquids. As expected, inhibition increases with the concentration, according to Eq. (1).

$I(\%)=\frac{100}{1+10^{B(A-\log c)}}$

where $I$ is the percentage of inhibition, $c$ is the concentration, and $A$ and $B$ are adjusted parameters, whose values for the pure ILs and the corresponding absolute average percentual deviation, AAD (Eq. (2)), are shown in Table 8.

$A A D=\frac{100}{N} \sum\left|\frac{I_{\text {exp }}-I_{a d j}}{I_{\text {exp }}}\right|$

where $I_{\exp }$ is the experimental percentage of inhibition, $I_{\text {adj }}$ is the inhibition obtained from the adjustment, and $N$ is the number of experimental data.
It is widely acknowledged that the bacterial bioluminescence reactions are indicative of the cellular metabolism of the bacteria, and a reduction in bioluminescence implies a decrease in cellular respiration (Perales et al. 2016). Consequently, the trend followed by these four ILs is $\mathrm{C}_{4} \mathrm{C}_{1} \mathrm{C}_{1} \mathrm{Im}$ TFSI $>\mathrm{C}_{4} \mathrm{C}_{1}$ pyrr TFSI $\approx \mathrm{EIm} \mathrm{NO}_{3}>$ EAN. A similar tendency was obtained for $\mathrm{EC}_{20} 30 \mathrm{~min}$, but for the values $\mathrm{EC}_{50}$ at $30 \mathrm{~min}$, the trend obtained is slightly different: $\mathrm{C}_{4} \mathrm{C}_{1} \mathrm{C}_{1} \mathrm{Im}$ TFSI $>$ EIm $\mathrm{NO}_{3}>\mathrm{C}_{4} \mathrm{C}_{1}$ pyrr TFSI $>$ EAN. These results agree with the previous idea that the protic and non-aromatic ILs are less toxic than aprotic and aromatic ones.

Taking into account the two criteria set out in the previous section, EAN, with $\mathrm{EC}_{50}$ at $30 \mathrm{~min}$ of $12582 \mathrm{mg} / \mathrm{L}$ value, higher than $1000 \mathrm{mg} / \mathrm{L}$ and $\mathrm{TU} \approx 9.10^{-3}$, is placed in the lowest group of toxicity and is harmless. The harmfulness of TFSI-based aprotic ILs depends on the cation, being practically harmless $(714 \mathrm{mg} / \mathrm{L}$ and $\mathrm{TU}=0.1)$ for the $\mathrm{C}_{4} \mathrm{C}_{1}$ pyrr TFSI, and for the $\mathrm{C}_{4} \mathrm{C}_{1} \mathrm{C}_{1}$ Im TFSI (almost) toxic according to both criteria $(1 \mathrm{mg} / \mathrm{L}<98.70 \mathrm{mg} / \mathrm{L}<100 \mathrm{mg} / \mathrm{L}$ and $\mathrm{TU} \approx 1$ ). A comparison of toxicity of 32 ILs between the most used as well as toluene (one of the most used VOCs) is shown in Fig. 2. The majority of these ILs are essentially harmless, and imidazolium cations with long alkyl chain length and $\mathrm{TFSI}^{-}$anion seem to be the most toxic, even more than toluene.
Table 5 EC $_{10}$ effective concentration values in $\mathrm{mg} / \mathrm{L}$ and the respective $95 \%$ confidence intervals, obtained after $5 \mathrm{~min}, 15 \mathrm{~min}$ and 30 min of exposure of the marine bacteria A. fischeri

\begin{tabular}{|c|c|c|c|}
\hline IL/mixture & $\begin{array}{l}\mathrm{EC}_{10} 5 \mathrm{~min} / \mathrm{mg} \cdot \mathrm{L}^{-1} \\
\text { (Lower; upper) limits }\end{array}$ & $\begin{array}{l}\mathrm{EC}_{10} 15 \mathrm{~min} / \mathrm{mg} \cdot \mathrm{L}^{-1} \\
\text { (Lower; upper) limits }\end{array}$ & $\begin{array}{l}\mathrm{EC}_{10} 30 \mathrm{~min} / \mathrm{mg} \cdot \mathrm{L}^{-1} \\
\text { (Lower; upper) limits }\end{array}$ \\
\hline \multicolumn{4}{|l|}{ Pure ionic liquids } \\
\hline EAN & $\begin{array}{l}2304.89 \\
(248.43 ; 4361.05)\end{array}$ & $\begin{array}{l}1609.79 \\
(560.06 ; 3163.56)\end{array}$ & $\begin{array}{l}1517.65 \\
(332.07 ; 2703.22)\end{array}$ \\
\hline $\mathrm{EIm} \mathrm{NO}_{3}$ & $\begin{array}{l}100.10 \\
(21.33 ; 179.99)\end{array}$ & $\begin{array}{l}103.80 \\
(22.16 ; 184.19)\end{array}$ & $\begin{array}{l}127.39 \\
(37.59 ; 214.25)\end{array}$ \\
\hline $\mathrm{C}_{4} \mathrm{C}_{1}$ pyrr TFSI & $\begin{array}{l}438.08 \\
(225.18 ; 650.98)\end{array}$ & $\begin{array}{l}254.32 \\
(146.51 ; 362.18)\end{array}$ & $\begin{array}{l}170.23 \\
(93.44 ; 247.12))\end{array}$ \\
\hline $\mathrm{C}_{4} \mathrm{C}_{1} \mathrm{C}_{1} \mathrm{Im}$ TFSI & $\begin{array}{l}23.25 \\
(0.00 ; 50.07)\end{array}$ & $\begin{array}{l}20.96 \\
(7.96 ; 33.95)\end{array}$ & $\begin{array}{l}20.34 \\
(12.63 ; 28.05)\end{array}$ \\
\hline \multicolumn{4}{|c|}{ IL + inorganic salt-saturated mixtures } \\
\hline $\mathrm{EAN}+\mathrm{LiNO}_{3} 2 \mathrm{~m}$ & $\begin{array}{l}6842.44 \\
5316.88 ; 8368.00)\end{array}$ & $\begin{array}{l}5920.72 \\
(3841.85 ; 7999.89)\end{array}$ & $\begin{array}{l}4701.17 \\
(1744.45 ; 7658.88)\end{array}$ \\
\hline $\mathrm{EAN}+\mathrm{Ca}\left(\mathrm{NO}_{3}\right)_{2} \cdot 4 \mathrm{H}_{2} \mathrm{O} 1 \mathrm{~m}$ & $\begin{array}{l}2732.16 \\
(1304.74 ; 4159.58)\end{array}$ & $\begin{array}{l}1938.08 \\
(632.90 ; 3046.27)\end{array}$ & $\begin{array}{l}1059.24 \\
(263.33 ; 1849.14)\end{array}$ \\
\hline $\mathrm{EAN}+\mathrm{Mg}\left(\mathrm{NO}_{3}\right)_{2} \cdot 6 \mathrm{H}_{2} \mathrm{O} 2 \mathrm{~m}$ & $\begin{array}{l}5469.35 \\
(3551.43 ; 7387.26)\end{array}$ & $\begin{array}{l}7049.21 \\
(5925.65 ; 8174.77)\end{array}$ & $\begin{array}{l}8409.28 \\
(6357.53 ; 10461.04)\end{array}$ \\
\hline $\mathrm{EAN}+\mathrm{Al}\left(\mathrm{NO}_{3}\right)_{3} \cdot 9 \mathrm{H}_{2} \mathrm{O} 2 \mathrm{~m}$ & $\begin{array}{l}8.04 \\
(3.01 ; 13.06)\end{array}$ & $\begin{array}{l}17.96 \\
(12.40 ; 21.53)\end{array}$ & $\begin{array}{l}14.30 \\
(10.29 ; 18.31)\end{array}$ \\
\hline $\mathrm{EIm} \mathrm{NO}_{3}+\mathrm{LiNO}_{3} 2 \mathrm{~m}$ & $\begin{array}{l}232.85 \\
(9.66 ; 455.18)\end{array}$ & $\begin{array}{l}251.51 \\
(6.98 ; 496.73)\end{array}$ & $\begin{array}{l}263.96 \\
(10.87 ; 515.83)\end{array}$ \\
\hline $\mathrm{C}_{4} \mathrm{C}_{1}$ pyrr TFSI + LiTFSI $1.5 \mathrm{~m}$ & $\begin{array}{l}35.88 \\
(17.01 ; 51.49)\end{array}$ & $\begin{array}{l}23.22 \\
(6.87 ; 39.12)\end{array}$ & $\begin{array}{l}21.12 \\
(8.52 ; 35.82)\end{array}$ \\
\hline $\mathrm{C}_{4} \mathrm{C}_{1} \mathrm{C}_{1} \mathrm{Im}$ TFSI + LiTFSI $1 \mathrm{~m}$ & $\begin{array}{l}6.35 \\
(0.15 ; 12.56)\end{array}$ & $\begin{array}{l}5.26 \\
(2.46 ; 8.07)\end{array}$ & $\begin{array}{l}5.45 \\
(3.64 ; 7.26)\end{array}$ \\
\hline
\end{tabular}


Table $6 \mathrm{EC}_{20}$ effective concentration values in $\mathrm{mg} / \mathrm{L}$ and the respective $95 \%$ confidence intervals, obtained after $5 \mathrm{~min}, 15 \mathrm{~min}$ and 30 min of exposure of the marine bacteria A. fischeri

\begin{tabular}{|c|c|c|c|}
\hline IL/mixture & $\begin{array}{l}\mathrm{EC}_{20} 5 \mathrm{~min} / \mathrm{mg} \cdot \mathrm{L}^{-1} \\
\text { (Lower; upper) limits }\end{array}$ & $\begin{array}{l}\mathrm{EC}_{20} 15 \mathrm{~min} / \mathrm{mg} \cdot \mathrm{L}^{-1} \\
\text { (Lower; upper) limits }\end{array}$ & $\begin{array}{l}\mathrm{EC}_{20} 30 \mathrm{~min} / \mathrm{mg} \cdot \mathrm{L}^{-1} \\
\text { (Lower; upper) limits }\end{array}$ \\
\hline \multicolumn{4}{|l|}{ Pure ionic liquids } \\
\hline EAN & $\begin{array}{l}4314.31 \\
(1548.95 ; 7081.66)\end{array}$ & $\begin{array}{l}3236.68 \\
(951.77 ; 5522.60)\end{array}$ & $\begin{array}{l}3012.33 \\
(1264.99 ; 4761.67)\end{array}$ \\
\hline $\mathrm{EIm} \mathrm{NO}_{3}$ & $\begin{array}{l}195.44 \\
(79.12 ; 312.90)\end{array}$ & $\begin{array}{l}194.19 \\
(79.98 ; 310.53)\end{array}$ & $\begin{array}{l}223.45 \\
(105.10 ; 342.82)\end{array}$ \\
\hline $\mathrm{C}_{4} \mathrm{C}_{1}$ pyrr TFSI & $\begin{array}{l}684.04 \\
(441.90 ; 926.09)\end{array}$ & $\begin{array}{l}416.73 \\
(286.18 ; 545.93)\end{array}$ & $\begin{array}{l}289.18 \\
(192.91 ; 386.85)\end{array}$ \\
\hline $\mathrm{C}_{4} \mathrm{C}_{1} \mathrm{C}_{1} \mathrm{Im}$ TFSI & $\begin{array}{l}46.34 \\
(5.74 ; 86.95)\end{array}$ & $\begin{array}{l}39.09 \\
(20.78 ; 57.40)\end{array}$ & $\begin{array}{l}36.45 \\
(26.05 ; 46.85)\end{array}$ \\
\hline \multicolumn{4}{|c|}{ IL + inorganic salt-saturated mixtures } \\
\hline $\mathrm{EAN}+\mathrm{LiNO}_{3} 2 \mathrm{~m}$ & $\begin{array}{l}8892.60 \\
(7412.30 ; 10373.90)\end{array}$ & $\begin{array}{l}7495.94 \\
(5603.85 ; 9386.04)\end{array}$ & $\begin{array}{l}6145.81 \\
(3301.99 ; 8988.58)\end{array}$ \\
\hline $\mathrm{EAN}+\mathrm{Ca}\left(\mathrm{NO}_{3}\right)_{2} \cdot 4 \mathrm{H}_{2} \mathrm{O} 1 \mathrm{~m}$ & $\begin{array}{l}3939.68 \\
(2427.26 ; 5450.11)\end{array}$ & $\begin{array}{l}2858.82 \\
(1475.52 ; 4240.12)\end{array}$ & $\begin{array}{l}1804.56 \\
(800.29 ; 2808.82)\end{array}$ \\
\hline $\mathrm{EAN}+\mathrm{Mg}\left(\mathrm{NO}_{3}\right)_{2} \cdot 6 \mathrm{H}_{2} \mathrm{O} 2 \mathrm{~m}$ & $\begin{array}{l}7471.07 \\
(5520.95 ; 9421.19)\end{array}$ & $\begin{array}{l}8933.00 \\
(7887.15 ; 9979.85)\end{array}$ & $\begin{array}{l}10222.13 \\
(8450.60 ; 11994.66)\end{array}$ \\
\hline $\mathrm{EAN}+\mathrm{Al}\left(\mathrm{NO}_{3}\right)_{3} \cdot 9 \mathrm{H}_{2} \mathrm{O} 2 \mathrm{~m}$ & $\begin{array}{l}15.21 \\
(8.47 ; 22.96)\end{array}$ & $\begin{array}{l}23.30 \\
(18.29 ; 27.31)\end{array}$ & $\begin{array}{l}19.25 \\
(15.84 ; 23.65)\end{array}$ \\
\hline $\mathrm{EIm} \mathrm{NO}_{3}+\mathrm{LiNO}_{3} 2 \mathrm{~m}$ & $\begin{array}{l}423.67 \\
(119.10 ; 727.77)\end{array}$ & $\begin{array}{l}435.29 \\
(118.19 ; 753.03)\end{array}$ & $\begin{array}{l}442.20 \\
(125.48 ; 759.18)\end{array}$ \\
\hline $\mathrm{C}_{4} \mathrm{C}_{1}$ pyrr TFSI + LiTFSI $1.5 \mathrm{~m}$ & $\begin{array}{l}89.11 \\
(56.09 ; 123.44)\end{array}$ & $\begin{array}{l}51.51 \\
(23.58 ; 79.99)\end{array}$ & $\begin{array}{l}44.11 \\
(23.08 ; 64.29)\end{array}$ \\
\hline $\mathrm{C}_{4} \mathrm{C}_{1} \mathrm{C}_{1} \mathrm{Im}$ TFSI + LiTFSI $1 \mathrm{~m}$ & $\begin{array}{l}13.01 \\
(3.31 ; 22.72)\end{array}$ & $\begin{array}{l}10.09 \\
(6.00 ; 14.18)\end{array}$ & $\begin{array}{l}9.88 \\
(7.39 ; 12.37)\end{array}$ \\
\hline
\end{tabular}

Microtox toxicity screening has been widely applied to different ionic liquids families; nevertheless, results of the selected ILs of this work are scarce. The case of EAN is especially striking, which became the first synthetized IL more than a century ago. Ventura et al. (2013) obtained values of $\mathrm{EC}_{50}$ at $5 \mathrm{~min}$ and $15 \mathrm{~min}$ of $130.85 \mathrm{mg} / \mathrm{L}$ and 87.23 $\mathrm{mg} / \mathrm{L}$, respectively, for $\mathrm{C}_{4} \mathrm{C}_{1} \mathrm{C}_{1}$ Im TFSI. These values are in very good concordance with our results for this IL and with that of Delgado-Mellado et al. (2019), who found values of $141 \mathrm{mg} / \mathrm{L}$ and $100 \mathrm{mg} / \mathrm{L}$ for the $\mathrm{EC}_{50}$ at $5 \mathrm{~min}$ and $15 \mathrm{~min}$, respectively. Montalbán et al. (2016) have also found lower values for $\mathrm{EC}_{50}$ at $30 \mathrm{~min}$ for pure $\mathrm{EAN}$, being relatively harmless and non-toxic according to both classifications indicated in this work. In the case of $\mathrm{C}_{4} \mathrm{C}_{1}$ pyrr TFSI, Viboud et al. (2012) have found $\mathrm{EC}_{50}$ at $15 \mathrm{~min}$ of $219 \mathrm{mg} / \mathrm{L}$, which is lower than our value but corresponds to the same toxicity group. Additionally, Ventura et al. (2013) analysed the effect of some TFSI-based ILs with the same alkyl length, being pyrrolidinium one of the most harmless of these aprotic ILs, also in agreement with our observations.

As a general conclusion, the results reported here confirm the idea that the protic ILs are generally less toxic than aprotic ones, and the non-aromatic ones are less toxic than aromatic ones. Additionally, the role of water solubility is important, where lower toxicity is related to higher hydrophilicity in every group (Peric et al. 2013; Ventura et al. 2013).

\section{Toxicity of salts -EAN mixtures}

The second part of this work studies the effect on toxicity regarding A. Fischeri bioluminescence inhibition of different salt additions to EAN IL. Figure 3 presents the percentage of bioluminescence inhibition of the bacteria with regards to the concentration of EAN - nitrate salt-saturated solutions. All of them follow a logistic equation (1), and the adjusted parameters values and AAD are collected in Table 8. Additionally, the values of $\mathrm{EC}_{10}, \mathrm{EC}_{20}$ and $\mathrm{EC}_{50}$ of these samples for $5 \mathrm{~min}, 15 \mathrm{~min}$ and $30 \mathrm{~min}$ of exposition are also shown in Tables 5, 6 and 7. Results showed that mixtures of EAN with the mono and divalent salts did not significantly affect the toxicity of the mixture with regards to the pure ionic liquid, but the addition of the aluminium salt had an important effect on the bioluminescence of A. Fischeri. This mixture is toxic in both classifications used in this article, as can be seen in Table 9. This behaviour may be related to the well-known antimicrobial and antibacterial effects of aluminium salts which are also related to the acidification of the sample as a consequence of this salt addition (being the $\mathrm{pH}$ lower than 4 for this salt, whereas for the other salt, it is always higher than 5) (Guida et al. 1991). As is widely 
Table $7 \quad \mathrm{EC}_{50}$ effective concentration values in $\mathrm{mg} / \mathrm{L}$ and the respective $95 \%$ confidence intervals, obtained after $5 \mathrm{~min}, 15 \mathrm{~min}$ and 30 min of exposure of the marine bacteria A. fischeri

\begin{tabular}{|c|c|c|c|}
\hline IL/mixture & $\begin{array}{l}\mathrm{EC}_{50} 5 \mathrm{~min} / \mathrm{mg} \cdot \mathrm{L}^{-1} \\
\text { (Lower; upper) limits }\end{array}$ & $\begin{array}{l}\mathrm{EC}_{50} 15 \mathrm{~min} / \mathrm{mg} \cdot \mathrm{L}^{-1} \\
\text { (Lower; upper) limits }\end{array}$ & $\begin{array}{l}\mathrm{EC}_{50} 30 \mathrm{~min} / \mathrm{mg} \cdot \mathrm{L}^{-1} \\
\text { (Lower; upper) limits }\end{array}$ \\
\hline \multicolumn{4}{|l|}{ Pure ionic liquids } \\
\hline EAN & $\begin{array}{l}12582.07 \\
(8186.64 ; 16977.50)\end{array}$ & $\begin{array}{l}10665.47 \\
(6650.14 ; 14680.80)\end{array}$ & $\begin{array}{l}9711.63 \\
(6561.46 ; 12860.79)\end{array}$ \\
\hline $\mathrm{EIm} \mathrm{NO}_{3}$ & $\begin{array}{l}612.55 \\
(395.90 ; 828.01)\end{array}$ & $\begin{array}{l}573.77 \\
(372.29 ; 774.55)\end{array}$ & $\begin{array}{l}597.89 \\
(408.00 ; 785.08)\end{array}$ \\
\hline $\mathrm{C}_{4} \mathrm{C}_{1}$ pyrr TFSI & $\begin{array}{l}1463.91 \\
(1162.13 ; 1765.69)\end{array}$ & $\begin{array}{l}964.58 \\
(791.32 ; 1137.88)\end{array}$ & $\begin{array}{l}714.43 \\
(577.92 ; 851.21)\end{array}$ \\
\hline $\mathrm{C}_{4} \mathrm{C}_{1} \mathrm{C}_{1} \mathrm{Im}$ TFSI & $\begin{array}{l}150.44 \\
(72.43 ; 228.49)\end{array}$ & $\begin{array}{l}113.32 \\
(82.29 ; 144.35)\end{array}$ & $\begin{array}{l}98.70 \\
(82.39 ; 115.01)\end{array}$ \\
\hline \multicolumn{4}{|c|}{ IL + inorganic salt-saturated mixtures } \\
\hline $\mathrm{EAN}+\mathrm{LiNO}_{3} 2 \mathrm{~m}$ & $\begin{array}{l}13911.23 \\
(12469.75 ; 15232.70)\end{array}$ & $\begin{array}{l}11210.37 \\
(9613.17 ; 12808.57)\end{array}$ & $\begin{array}{l}9706.72 \\
(7233.87 ; 12179.58)\end{array}$ \\
\hline $\mathrm{EAN}+\mathrm{Ca}\left(\mathrm{NO}_{3}\right)_{2} \cdot 4 \mathrm{H}_{2} \mathrm{O} 1 \mathrm{~m}$ & $\begin{array}{l}7354.41 \\
(5672.26 ; 9036.56)\end{array}$ & $\begin{array}{l}6064.77 \\
(4343.18 ; 7784.36)\end{array}$ & $\begin{array}{l}4502.32 \\
(3067.63 ; 5937.02)\end{array}$ \\
\hline $\mathrm{EAN}+\mathrm{Mg}\left(\mathrm{NO}_{3}\right)_{2} \cdot 6 \mathrm{H}_{2} \mathrm{O} 2 \mathrm{~m}$ & $\begin{array}{l}12724.84 \\
(10834.31 ; 14615.38)\end{array}$ & $\begin{array}{l}13384.92 \\
(12522.40 ; 14247.45)\end{array}$ & $\begin{array}{l}14266.92 \\
(13128.37 ; 15403.46)\end{array}$ \\
\hline $\mathrm{EAN}+\mathrm{Al}\left(\mathrm{NO}_{3}\right)_{3} \cdot 9 \mathrm{H}_{2} \mathrm{O} 2 \mathrm{~m}$ & $\begin{array}{l}45.22 \\
(32.45 ; 58.98)\end{array}$ & $\begin{array}{l}37.34 \\
(33.10 ; 41.59)\end{array}$ & $\begin{array}{l}32.25 \\
(29.84 ; 36.65)\end{array}$ \\
\hline $\mathrm{EIm} \mathrm{NO}_{3}+\mathrm{LiNO}_{3} 2 \mathrm{~m}$ & $\begin{array}{l}1178.11 \\
(691.19 ; 1665.78)\end{array}$ & $\begin{array}{l}1114.08 \\
(644.19 ; 1583.21)\end{array}$ & $\begin{array}{l}1073.03 \\
(626.44 ; 1520.48)\end{array}$ \\
\hline $\mathrm{C}_{4} \mathrm{C}_{1}$ pyrr TFSI + LiTFSI $1.5 \mathrm{~m}$ & $\begin{array}{l}453.19 \\
(360.94 ; 547.22)\end{array}$ & $\begin{array}{l}208.10 \\
(142.51 ; 274.71)\end{array}$ & $\begin{array}{l}149.60 \\
(108.86 ; 189.91)\end{array}$ \\
\hline $\mathrm{C}_{4} \mathrm{C}_{1} \mathrm{C}_{1} \mathrm{Im}$ TFSI + LiTFSI $1 \mathrm{~m}$ & $\begin{array}{l}44.26 \\
(24.69 ; 63.82)\end{array}$ & $\begin{array}{l}30.63 \\
(23.26 ; 40.00)\end{array}$ & $\begin{array}{l}27.24 \\
(23.17 ; 31.32)\end{array}$ \\
\hline
\end{tabular}

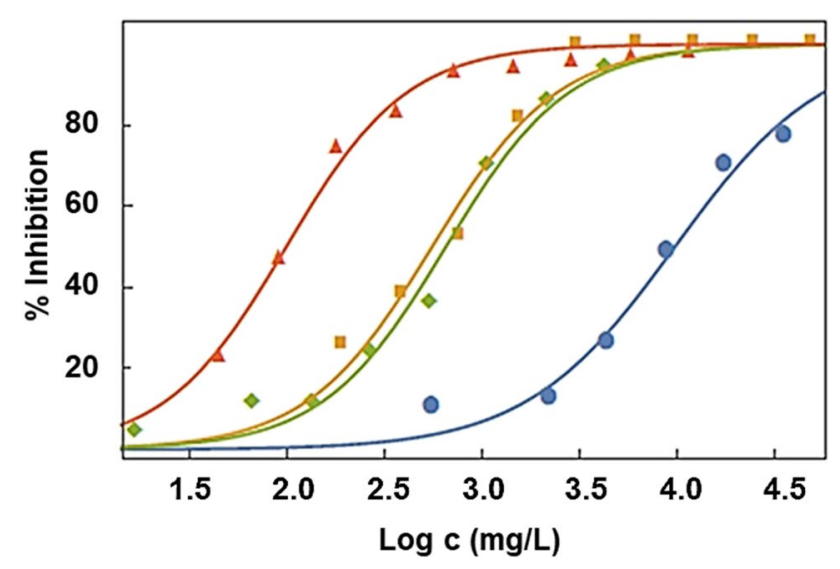

Fig. 1 Inhibition of bioluminescence for $30 \mathrm{~min}$ of exposure against the logarithm of the concentration of the four pure ionic liquids: (red triangle) $\mathrm{C}_{4} \mathrm{C}_{1} \mathrm{C}_{1}$ Im TFSI, (green rhombus) $\mathrm{C}_{4} \mathrm{C}_{1}$ pyrr TFSI, (orange square) $\mathrm{EIm} \mathrm{NO}_{3}$ and (blue circle) EAN. Lines represent the fitting of the experimental results to Eq. (1)

acknowledged, aluminium in a solid state plays a key role in the environment, but due to high reactivity, it is difficult to find in a free state in nature. At neutral or weakly acidic $\mathrm{pH}$, it is present in the form of insoluble oxides and aluminosilicates. However, for high acidic media, aluminium
Table 8 Adjustable parameters (with the standard deviation) of the logistic equation (Eq. (1)) and the absolute average percentual deviation (AAD) (Eq. (2))

\begin{tabular}{|c|c|c|c|}
\hline Sample & A & $\mathrm{B}$ & $\operatorname{AAD}(\%)$ \\
\hline EAN & $3.99 \pm 0.04$ & $1.14 \pm 0.13$ & 18.1 \\
\hline $\mathrm{EIm} \mathrm{NO}_{3}$ & $2.75 \pm 0.04$ & $1.35 \pm 0.17$ & 6.3 \\
\hline $\mathrm{C}_{4} \mathrm{C}_{1}$ pyrr TFSI & $2.81 \pm 0.04$ & $1.38 \pm 0.15$ & 24.6 \\
\hline $\mathrm{C}_{4} \mathrm{C}_{1} \mathrm{C}_{1} \operatorname{Im}$ TFSI & $2.00 \pm 0.02$ & $1.40 \pm 0.10$ & 3.2 \\
\hline $\mathrm{EAN}+\mathrm{LiNO}_{3} 2 \mathrm{~m}$ & $3.96 \pm 0.03$ & $2.6 \pm 0.4$ & 52.3 \\
\hline $\mathrm{EAN}+\mathrm{Ca}\left(\mathrm{NO}_{3}\right)_{2} \cdot 4 \mathrm{H}_{2} \mathrm{O} 1 \mathrm{~m}$ & $3.67 \pm 0.06$ & $1.5 \pm 0.3$ & 13.7 \\
\hline $\mathrm{EAN}+\mathrm{Mg}\left(\mathrm{NO}_{3}\right)_{2} \cdot 6 \mathrm{H}_{2} \mathrm{O} 2 \mathrm{~m}$ & $4.12 \pm 0.01$ & $3.4 \pm 0.2$ & 41.4 \\
\hline $\mathrm{EAN}+\mathrm{Al}\left(\mathrm{NO}_{3}\right)_{3} \cdot 9 \mathrm{H}_{2} \mathrm{O} 2 \mathrm{~m}$ & $1.49 \pm 0.01$ & $2.47 \pm 0.10$ & 1.7 \\
\hline $\mathrm{EIm} \mathrm{NO}_{3}+\mathrm{LiNO}_{3} 2 \mathrm{~m}$ & $2.16 \pm 0.04$ & $1.35 \pm 0.08$ & 6.3 \\
\hline $\mathrm{C}_{4} \mathrm{C}_{1}$ pyrr TFSI + LiTFSI $1.5 \mathrm{~m}$ & $2.20 \pm 0.04$ & $1.18 \pm 0.10$ & 11.4 \\
\hline $\mathrm{C}_{4} \mathrm{C}_{1} \mathrm{C}_{1} \mathrm{Im}$ TFSI + LiTFSI $1 \mathrm{~m}$ & $1.45 \pm 0.02$ & $1.39 \pm 0.08$ & 4.5 \\
\hline
\end{tabular}

is solubilised into a phytotoxic form (Matsumoto 2000). Since under these acidic conditions, it is a polyvalent cation that binds strongly to negative charges, usually the carboxyl groups in cell wall molecules affect cell division, cell extension or nutrient transport and provoke cell growth disruption and serious perturbation of the normal metabolism of living organisms (Haug 1984; Jones and Ryan 2016). Contrarily, 


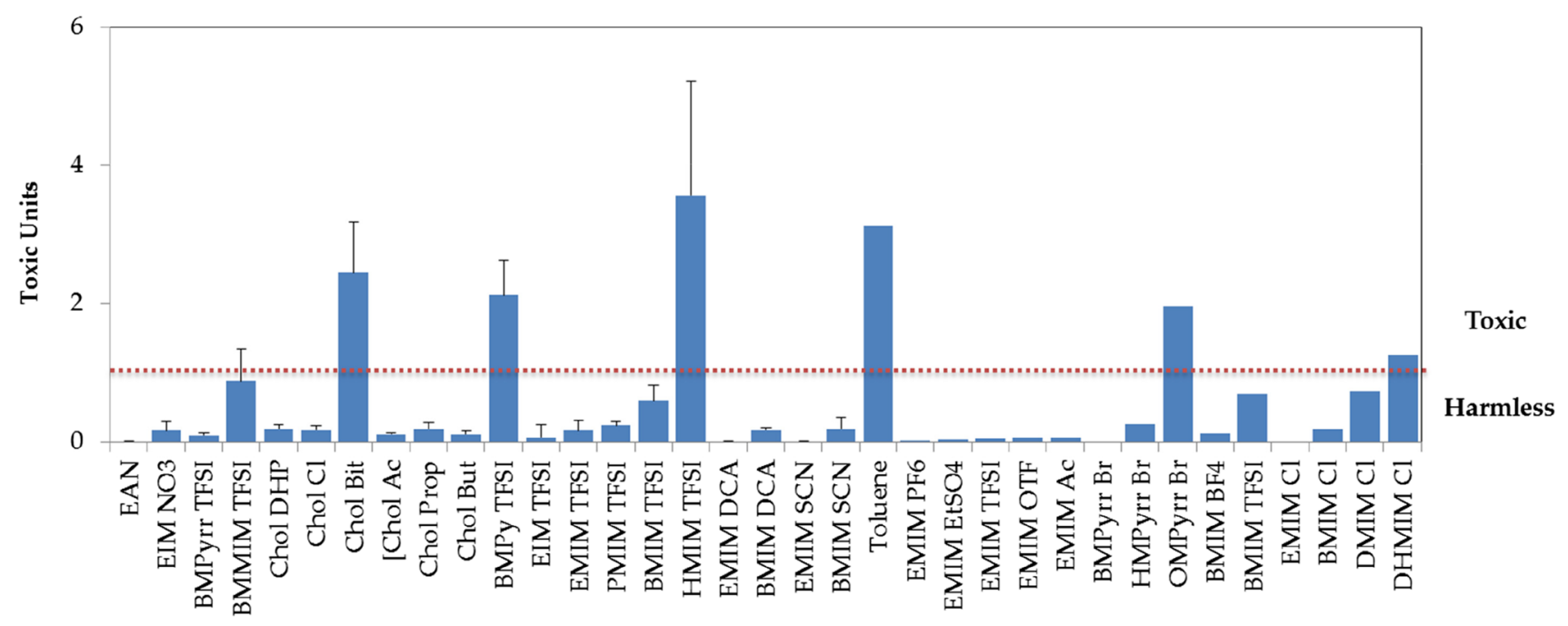

Fig. 2 Comparison of the toxicity level (Chang et al. 2013) of the ILs studied here and some of the literature (error bars were included if the uncertainty intervals were published). Cholinium dihidrogen phosphate (Chol DHP), choline chloride $(\mathrm{Chol} \mathrm{Cl})$, cholinium bitartatre (Chol Bit), choline acetate (Chol Ac), choline propanoate (Chol Prop) and choline butanoate (Chol But) (Ventura et al. 2014); 1-butyl4-methylpyridiniumbis (trifluoromethylsulfonyl)imide (BMPy TFSI), 1-ethylimidazolium bis(trifluoromethylsulfonyl) imide (EMIM TFSI), 1-ethyl-3-methylimidazolium bis(trifluoromethylsulfonyl) imide (EMIM TFSI), 1-propyl-3-methylimidazolium bis(trifluoromethylsulfonyl) imide (PMIM TFSI), 1-butyl-3methylimidazolium bis(trifluoromethylsulfonyl) imide (BMIM TFSI), 1-ethyl-3-methylimidazolium bis(trifluoromethylsulfonyl) imide (EMIM TFSI), 1-hexyl-3-methylimidazolium bis(trifluoromethylsulfonyl) imide (HMIM TFSI), 1-ethyl-3-methylimidazolium dicyanamide (EMIM DCA), 1-butyl-3-methylimidazolium dicyanamide (BMIM DCA), 1-ethyl-3-methylimidazolium

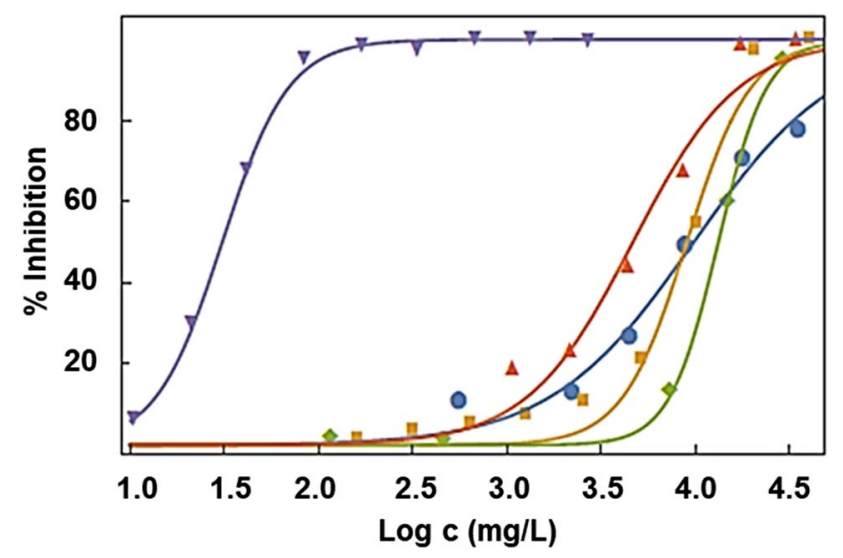

Fig. 3 Inhibition of bioluminescence for $30 \mathrm{~min}$ of exposure against the logarithm of the concentration of the (blue circle) pure EAN, and mixtures with the four nitrate salts: (orange square) EAN-lithium nitrate mixture, (green rhombus) EAN-magnesium nitrate mixture, (up red triangle) EAN-calcium nitrate mixture and (down blue triangle) EAN-aluminium nitrate mixture. Lines represent the fitting of the experimental results to Eq. (1) thiocyanate (EMIM SCN), 1-butyl-3-methylimidazolium thiocyanate (BMIM SCN) (Delgado-Mellado et al. 2019); toluene (Hernández-Fernández et al. 2015); 1-ethyl-3-methylimidazolium chloride (EMIM Cl), 1-ethyl-3-methylimidazolium hexafluorophosphate (EMIM $\mathrm{PF}_{6}$ ), 1-ethyl-3-methylimidazolium ethylsulphate (EMIM $\left.\mathrm{EtSO}_{4}\right)$, 1-ethyl-3-methylimidazolium bis((trifluoromethyl) sulfonyl) amide (EMIM TFSI), 1-ethyl-3-methylimidazolium triflate (EMIM OTF), 1-ethyl-3-methylimidazolium acetate (EMIM Ac), 1-butyl-1methylpyrrolidinium bromide (BMPyrr Br), 1-hexyl-1-methylpyrrolidinium bromide (HMPyrr $\mathrm{Br}$ ), 1-octyl-1-methylpyrrolidinium bromide (OMPyrr Br), 1-butyl-3-methylimidazolium tetrafluoroborate (BMIM $\mathrm{BF}_{4}$ ), 1-butyl-3-methylimidazolium chloride (BMIM Cl), 1-butyl-3-methylimidazolium bis((trifluoromethyl) sulfonyl)amide (BMIM TFSI) (Ibrahim et al. 2017); 1-decyl-3-methylimidazolium chloride (DMIM Cl), 1-hexadecyl-3-methylimidazolium chloride (DHMIM Cl) (Kang et al. 2020)

Table 9 Toxicity identification of the EAN-nitrate salt mixtures using the criteria of Passino and Smith (1987) and Chang et al. (2013)

\begin{tabular}{lll}
\hline IL/mixture & $\begin{array}{l}\text { Passino and Smith } \\
(1987)\end{array}$ & Chang et al. (2013) \\
\hline EAN & Relatively harmless & Non-toxic \\
$\mathrm{EAN}+\mathrm{LiNO}_{3} 2 \mathrm{~m}$ & Relatively harmless & Non-toxic \\
$\mathrm{EAN}+\mathrm{Ca}\left(\mathrm{NO}_{3}\right)_{2} 1 \mathrm{~m}$ & Relatively harmless & Non-toxic \\
$\mathrm{EAN}+\mathrm{Mg}\left(\mathrm{NO}_{3}\right)_{2} 2 \mathrm{~m}$ & Relatively harmless & Non-toxic \\
$\mathrm{EAN}+\mathrm{Al}\left(\mathrm{NO}_{3}\right)_{3} 2 \mathrm{~m}$ & Toxic & Toxic \\
\hline
\end{tabular}

$\mathrm{Li}^{+}, \mathrm{Ca}^{+2}$ and $\mathrm{Mg}^{+2}$ cations do not exert any appreciable influence on the toxicity of the IL. Indeed, these cations play different beneficial functions in cells since they are oligoelements, i.e. metal or metalloid ions that have important roles such as constituents of cell tissues or as catalysers of chemical reactions of the cell metabolism (Carvalho et al. 2015). Specifically, lithium plays a special role in brain diseases, for example, through the inhibition of the inositol, which is sugar involved in the ability of neurons to exchange signals. 
Lithium lowers inositol levels, calming overactive neurons (Pilcher 2003). $\mathrm{Mg}^{+2}$ and $\mathrm{Ca}^{+2}$ have intermediate binding strengths to organic ligands. In the particular case of $\mathrm{Ca}^{+2}$, it works for a charge carrier and for signal transmission inside the cells (Crichton 2017).

\section{Toxicity of IL-lithium salt mixtures}

The last part of this article is the analysis of the effect of the mixture of lithium salt and different ionic liquids. Figure 4 shows the comparison of the inhibition of bioluminescence of A. fischeri against the logarithm of concentration for 30 min of exposure of the four pure ionic liquids EAN, EIm $\mathrm{NO}_{3}, \mathrm{C}_{4} \mathrm{C}_{1}$ pyrr TFSI and $\mathrm{C}_{4} \mathrm{C}_{1} \mathrm{C}_{1}$ Im TFSI with the corresponding saturated lithium salt binary mixture, $\mathrm{Li} \mathrm{NO}_{3}$ for the protic ILs and Li TFSI for the aprotic ones. The adjusted parameters of Eq. (1) and AAD values are shown in Table 8. Additionally, the values of $\mathrm{EC}_{10}, \mathrm{EC}_{20}$ and $\mathrm{EC}_{50}$ of these samples, pure ILs and mixtures, for $5 \mathrm{~min}, 15 \mathrm{~min}$ and 30 min of exposition are also shown in Tables 5, 6 and 7 .

Changes in bioluminescence inhibition as a consequence of salt addition are strongly dependent on the ionic liquid-salt mixture in terms of $\mathrm{EC}_{50}$. Two behaviours can be observed, the first one for protic ILs, where the addition of lithium nitrate salt does not affect the toxicity or even reduce it, with regard to pure ILs and aprotic ILs, where the LiTFSI addition induces an increase in toxicity of mixture with regard to pure IL. Thus, pure EAN and EAN $+\mathrm{LiNO}_{3}$ mixture present results of $\mathrm{EC}_{50}$ at 30 min which suggests that the toxicity of the mixture is similar to that of the pure IL, although the inhibition of the lowest concentrations
$\left(\mathrm{EC}_{20}\right.$ and $\left.\mathrm{EC}_{10}\right)$ is lower for the mixture than for the pure IL. Likewise, the case of the mixture of $\mathrm{EIm} \mathrm{NO}_{3}+\mathrm{Li}$ salt is especially interesting. It presents lower toxicity than pure IL following the Passino and Smith classification since the $\mathrm{EC}_{50}$ at $30 \mathrm{~min}$ increases from 598 to $1073 \mathrm{mg} / \mathrm{L}$ for pure IL and mixture, respectively. This can be due to the different effects of IL and salt on the bacteria, being the salt relatively harmless (Viboud et al. 2012), reducing in the mixture the concentration of the most toxic part, the IL.

On the contrary, aprotic IL-lithium salt mixtures display a different behaviour than protic ones: The toxicity seems to increase significantly with the addition of lithium salt. Hence, the addition of Li TFSI reduced the $\mathrm{EC}_{50}$ of $\mathrm{C}_{4} \mathrm{C}_{1} \mathrm{C}_{1}$ Im TFSI and $\mathrm{C}_{4} \mathrm{C}_{1}$ Pyr TFSI by a factor of four in all the exposure times. As previously pointed out and taking into account that Viboud et al. (2012) classify the Li TFSI salt in the lowest toxicity group $\left(\mathrm{EC}_{50}>1000 \mathrm{mg} / \mathrm{L}\right)$, this $\mathrm{EC}_{50}$ reduction with the lithium salt doping is unexpected, but can be explained by the augmentation of the concentration of $\mathrm{TFSI}^{-}$ion after the addition of the salt to the IL with the common anion, which increases the hydrophobicity of the sample, closely related with the toxicity towards A. Fischeri bioluminescence, as pointed out previously in "Toxicity of pure ILs." However, this important $\mathrm{EC}_{50}$ reduction is not enough to change the toxicity level after salt addition; slightly toxic and toxic for Passino and Smith and Chang criteria, as can be seen in Table 10.

As a general observation, the addition of the lithium salts does not change the effect of these compounds on the bioluminescence of $A$. Fischeri bacteria, and the two criteria used in this study showed similar results although
Fig. 4 Comparison of the inhibition of bioluminescence of $A$. fischeri against the logarithm of the concentration of the four (blue circle) pure ionic liquids (a) EAN, (b) EIm $\mathrm{NO}_{3}$, (c) $\mathrm{C}_{4} \mathrm{C}_{1}$ pyrr TFSI and (d) $\mathrm{C}_{4} \mathrm{C}_{1} \mathrm{C}_{1}$ Im TFSI, and, after $30 \mathrm{~min}$ of exposure, with the corresponding (orange square) saturated lithium salt. Lines represent the fitting of the experimental results to Eq. (1)
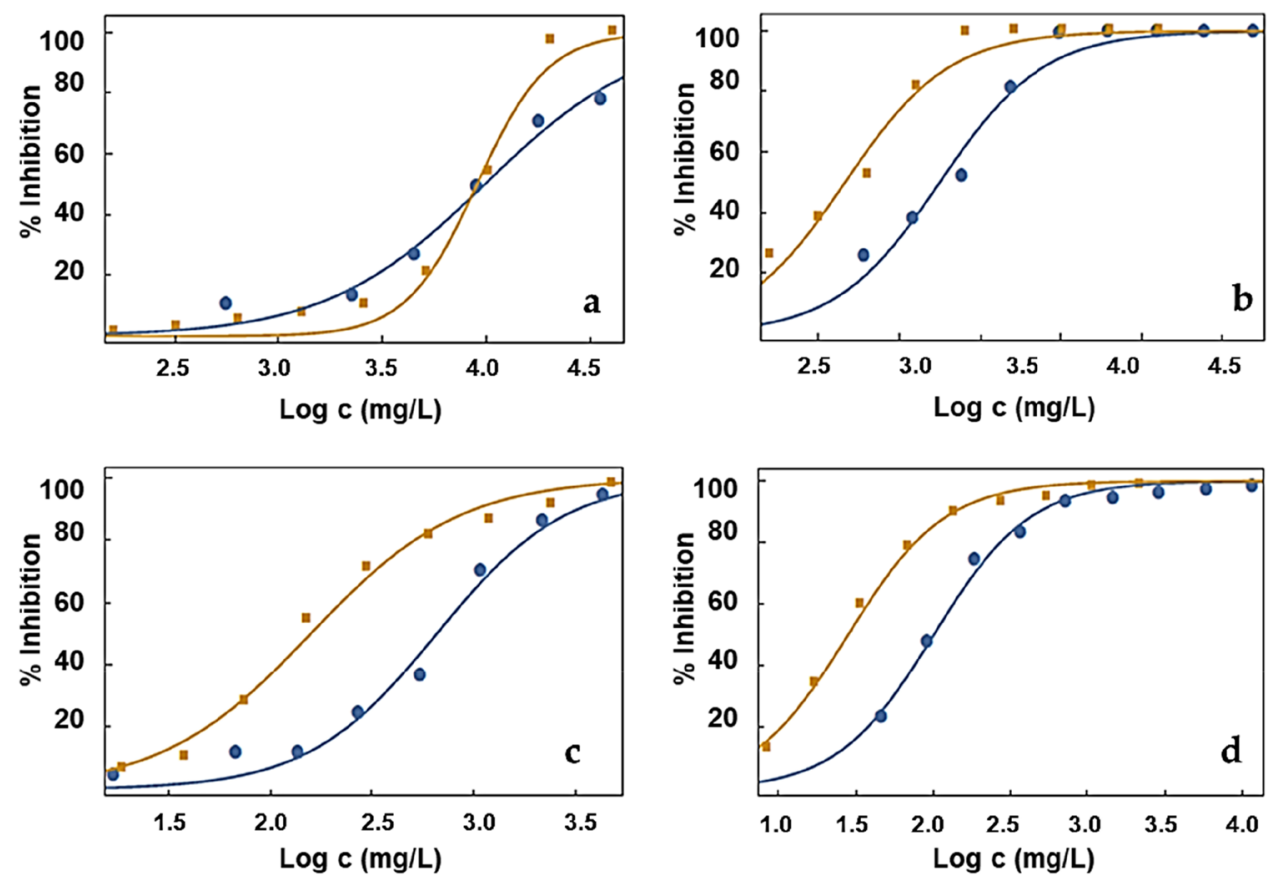
Table 10 Toxicity identification of the IL-lithium salt mixtures using the criteria of Passino and Smith (1987) and Chang et al. (2013)

\begin{tabular}{|c|c|c|}
\hline IL/mixture & $\begin{array}{l}\text { Passino and Smith } \\
\text { (1987) }\end{array}$ & Chang et al. (2013) \\
\hline EAN & Relatively harmless & Non-toxic \\
\hline $\mathrm{EAN}+\mathrm{LiNO}_{3}$ & Relatively harmless & Non-toxic \\
\hline $\mathrm{EIm} \mathrm{NO}_{3}$ & Practically harmless & Non-toxic \\
\hline $\mathrm{EIm} \mathrm{NO}_{3}+\mathrm{LiNO}_{3}$ & Relatively harmless & Non-toxic \\
\hline $\mathrm{C}_{4} \mathrm{C}_{1}$ pyrr TFSI & Practically harmless & Non-toxic \\
\hline $\begin{array}{l}\mathrm{C}_{4} \mathrm{C}_{1} \text { pyrr TFSI + } \\
\text { LiTFSI }\end{array}$ & Practically harmless & Non-toxic \\
\hline $\mathrm{C}_{4} \mathrm{C}_{1} \mathrm{C}_{1}$ Im TFSI & Slightly toxic & Toxic \\
\hline $\begin{array}{l}\mathrm{C}_{4} \mathrm{C}_{1} \mathrm{C}_{1} \mathrm{Im} \text { TFSI }+ \\
\text { LiTFSI }\end{array}$ & Slightly toxic & Toxic \\
\hline
\end{tabular}

small differences can be found, especially due to the fact that Passino and Smith stabilised five levels of toxicity and Chang et al. only four.

Furthermore, it is important to point out that the extrapolation of these results to other toxicity endpoints cannot be done easily because the response is highly dependent on trophic levels (Perales et al. 2018). Whilst there are no references about ecotoxicity changes on ILs after salt addition, the results of Sixto et al. (2021) are of special interest. The aforementioned study analysed the effect of EAN and EAN-lithium nitrate mixture (equally harmless to A. Fischeri) on the respiration of two soils with different organic matter content, concluding that both pure IL and mixture strongly affect the soil respiration and that the organic matter content can mitigate the negative effect of lithium salt. All these observations highlight the need to increase and specify the knowledge of the impact of these ionic compounds and their mixtures in order to set up appropriate recovery and recycling procedures.

\section{Conclusions}

In this work, the ecotoxicity of two protic ILs (ethylammonium nitrate and ethylimidazolium nitrate) and two aprotic ILs (butylmethylpyrrolidinium bis (trifluoromethylsulfonyl) imide and butyldimethylimidazolium bis (trifluoromethylsulfonyl)imide) pure and binary mixtures with different inorganic salts of electrochemical interest were tested towards changes on the bioluminescence of the bacteria Aliivibrio fischeri, using the Microtox ${ }^{\circledR}$ standard toxicity test.

The main conclusions of this work are as follows.

- Protic ILs are less toxic than aprotic ones, and that nonaromatic ones are generally less toxic than aromatic ones. Moreover, the role of water solubility is important, where lower toxicity is related to higher hydrophilicity in every group.

- Mixtures of EAN with the mono- and divalent salts do not significantly affect the toxicity of the mixture with regards to the pure ionic liquid, but the addition of an aluminium salt has an important effect on the bioluminescence of A. Fischeri, where this mixture is the most toxic of those studied.

- The effect of the addition of lithium salt strongly depends on the IL of the mixture: Protic ILs do not significantly modify the $\mathrm{EC}_{50}$ with regard to that of pure IL or even lead to slight increases of it, indicating a reduction of toxicity. Nevertheless, for the aprotic ILs, the effect of salt addition clearly increases the toxicity of the mixture in terms of $\mathrm{EC}_{50}$, although no changes on the toxicity step of the two criteria here applied can be observed.

- The two criteria used in this paper to classify the toxicity concerning marine bacteria A. Fischeri bioluminescence inhibition are comparable.

Author contribution Conceptualization: J.J.P., J.S. and L.M.V. Methodology and data measurements: P.V., J.J.P. and M.V.

Data analysis, tables and figures preparation: J.J.P., P.V., M.V. and J.S.

Writing—original draft preparation: J.J.P., P.V., L.M.V., M.V. and J.S.

Funding acquisition: M.V, J.S. and L.M.V.

All authors have read and agreed to the published version of the manuscript

Funding Open Access funding provided thanks to the CRUE-CSIC agreement with Springer Nature. This work was supported by the Spanish Ministry of Economy and Competitiveness and FEDER Program through the MAT2017-89239-C2-1-P project as well as by the Xunta de Galicia through the GRC ED431C 2020/10 project and the Galician Network of Ionic Liquids (ReGaLIs) ED431D 2017/06. P. Vallet and J. J. Parajó wish to thank the FPI program from the Spanish Ministry of Science, Education and Universities and the I2C postdoctoral program of the Xunta de Galicia for their support in funding the study.

Data availability Not applicable

\section{Declarations}

Ethics approval and consent to participate Not applicable.

Consent for publication Not applicable.

Competing interests The authors declare no competing interests.

Open Access This article is licensed under a Creative Commons Attribution 4.0 International License, which permits use, sharing, adaptation, distribution and reproduction in any medium or format, as long as you give appropriate credit to the original author(s) and the source, provide a link to the Creative Commons licence, and indicate if changes 
were made. The images or other third party material in this article are included in the article's Creative Commons licence, unless indicated otherwise in a credit line to the material. If material is not included in the article's Creative Commons licence and your intended use is not permitted by statutory regulation or exceeds the permitted use, you will need to obtain permission directly from the copyright holder. To view a copy of this licence, visit http://creativecommons.org/licenses/by/4.0/.

\section{References}

Balducci A (2017) Ionic liquids in lithium-ion batteries. Top Curr Chem 375:1-27. https://doi.org/10.1007/s41061-017-0109-8

Carvalho DC, Coelho LM, Acevedo MSMSF, Coelho NMM (2015) The oligoelements. In: Guardia M de la, Garrigues S (eds) Handbook of Mineral Elements in Food, First Edit. John Wiley \& Sons, Ltd, pp 109-122

Chang SC, Wang YF, You SJ, Kuo YM, Tsai CH, Wang LC, Hsu PY (2013) Toxicity evaluation of fly ash by Microtox®. Aerosol Air Qual Res 13:1002-1008. https://doi.org/10.4209/aaqr.2012. 10.0267

Commission E (2006) SE D, Co KG, Schöpf TJ, \& Renner N. regulation (EC) No. 1907/2006 of the European parliament and of the council of 18 December 2006 concerning the registration, evaluation, authorisation and restriction of chemicals (REACH)

Crichton RR (2017) Metal toxicity - an introduction. In: Crichton RR, Ward RJ, Hider RC (eds) Metal Chelation in Medicine, First edit. The Royal Society of Chemistry, pp 1-23. https://doi.org/10.1039/ 9781782623892-00001

Delgado-Mellado N, Ayuso M, Villar-Chavero MM, García J, Rodríguez F (2019) Ecotoxicity evaluation towards Vibrio fischeri of imidazolium- and pyridinium-based ionic liquids for their use in separation processes. SN Appl Sci 1:896. https://doi.org/10.1007/ s42452-019-0916-3

Guida L, Saidi Z, Hughes MN, Poole RK (1991) Aluminium toxicity and binding to Escherichia coli. Arch Microbiol 156:507-512

Gutiérrez A, Atilhan M, Aparicio S (2018) Theoretical study of oil desulfuration by ammonium-based deep eutectic solvents. Energy Fuels 32:7497-7507. https://doi.org/10.1021/acs.energyfuels. $8 \mathrm{~b} 01403$

Haug A (1984) Molecular aspects of aluminum toxicity. CRC Crit Rev Plant Sci 1:345-373. https://doi.org/10.1080/07352688409382184

Hernández-Fernández FJ, Bayo J, Ríos APDL, Vicente MA, Bernal FJ (2015) Ecotoxicology and environmental safety discovering less toxic ionic liquids by using the Microtox toxicity test. Ecotoxicol Environ Saf 116:29-33. https://doi.org/10.1016/j.ecoenv. 2015.02.034

Ibrahim M, Mutalib A, Mutalib A (2017) Ecotoxicity of and ionic liquids towards Vibrio fischeri : experimental and QSAR studies. In: Handy S (ed) Progress and Developments in Ionic Liquids. INTECH, pp 429-449. https://doi.org/10.5772/65795

Johnson BT (2005) Microtox $®$ acute toxicity test. Small-Scale Freshw Toxic Investig Vol 1 - Toxic Test Methods 1:69-105. https://doi. org/10.1007/1-4020-3120-3_2

Jones DL, Ryan PR (2016) Aluminum toxicity. In: Encyclopedia of Applied Plant Sciences, Second Edi. Elsevier, pp 211-218

Kang X, Chen Z, Zhao Y (2020) Assessing the ecotoxicity of ionic liquids on Vibrio fischeri using electrostatic potential descriptors. J Hazard Mater 397:122761. https://doi.org/10.1016/j.jhazmat. 2020.122761

Kim J-K, Lim D-H, Scheers J, Wilken S, Johansson P, Ahn J-H, Matic A, Jacobsson P (2011) Properties of N-butyl-N-methyl-pyrrolidinium bis(trifluoromethanesulfonyl) imide based electrolytes as a function of lithium bis(trifluoromethanesulfonyl) imide doping. $\mathrm{J}$ Korean Electrochem Soc 14:92-97. https://doi.org/10.5229/JKES. 2011.14.2.092

Luis P, Garea A, Irabien A (2010) Quantitative structure-activity relationships (QSARs ) to estimate ionic liquids ecotoxicity EC50 (Vibrio fischeri). J Mol Liq 152:28-33. https://doi.org/10.1016/j. molliq.2009.12.008

Matsumoto H (2000) Cell biology of aluminum toxicity and tolerance in higher plants. Int Rev Cytol 200:1-46. https://doi.org/10.1016/ s0074-7696(00)00001-2

Menne S, Pires J, Anouti M, Balducci A (2013) Protic ionic liquids as electrolytes for lithium-ion batteries. Electrochem Comm 31:3941. https://doi.org/10.1016/j.elecom.2013.02.026

Montalbán MG, Hidalgo JM, Collado-González M, Díaz Baños FG, Víllora G (2016) Assessing chemical toxicity of ionic liquids on Vibrio fischeri: correlation with structure and composition. Chemosphere 155:405-414. https://doi.org/10.1016/j.chemosphere. 2016.04.042

Moreno D, Ferro VR, de Riva J, Santiago R, Moya C, Larriba M, Palomar J (2018) Absorption refrigeration cycles based on ionic liquids: refrigerant/absorbent selection by thermodynamic and process analysis. Appl Energy 213:179-194. https://doi.org/10. 1016/j.apenergy.2018.01.034

Nakamoto H, Watanabe M (2007) Brønsted acid-base ionic liquids for fuel cell electrolytes. Chem Commun 2539-2541. https://doi.org/ 10.1039/B618953A

Otero I, López ER, Reichelt M, Villanueva M, Salgado J, Fernández J (2014) Ionic liquids based on phosphonium cations As neat lubricants or lubricant additives for a steel/steel contact. ACS Appl Mater Interfaces 6:13115-13128. https://doi.org/10.1021/am502 $980 \mathrm{~m}$

Parajó JJ, Macário IPE, De Gaetano Y, Dupont L, Salgado J, Pereira JL, Gonçalves FJM, Mohamadou A, Ventura SPM (2019) Glycine-betaine-derived ionic liquids: synthesis, characterization and ecotoxicological evaluation. Ecotoxicol Environ Saf 184:109580. https://doi.org/10.1016/j.ecoenv.2019.109580

Passino DRM, Smith SB (1987) Acute bioassays and hazard evaluation of representative contaminants detected in great lakes fish. Environ Toxicol Chem 6:901-907. https://doi.org/10.1002/etc. 5620061111

Perales E, García CB, Lomba L, Aldea L, García JI, Giner B (2016) Comparative ecotoxicology study of two neoteric solvents: Imidazolium ionic liquid vs. glycerol derivative. Ecotoxicol Environ Saf 132:429-434. https://doi.org/10.1016/j.ecoenv.2016.05.021

Perales E, Lomba L, García-Escudero M, Sarasa E, Lafuente CE, Giner B (2018) Toxicological study of some ionic liquids. Green Process Synth 7:287-295

Peric B, Sierra J, Martí E, Cruañas R, Garau MA, Arning J, BottinWeber U, Stolte S (2013) (Eco)toxicity and biodegradability of selected protic and aprotic ionic liquids. J Hazard Mater 261:99-105

Pilcher HR (2003) The ups and downs of lithium. Nature 425:118-120

Rana UA, Bayley PM, Vijayaraghavan R, Howlett P, MacFarlane DR, Forsyth M (2010) Proton transport in choline dihydrogen phosphate/H3PO4 mixtures. Phys Chem Chem Phys 12:11291. https:// doi.org/10.1039/c0cp00156b

Rodríguez H, Brennecke J (2006) Temperature and composition dependence of the density and viscosity of binary mixtures of water+ ionic liquid. J Chem Eng Data 51:2145-2155. https://doi. org/10.1021/je0602824

Rogers RD, Seddon KR (2003) Ionic liquids - solvents of the future? Science (80-) 302:792-793

Salgado J, Parajó JJ, Villanueva M, Rodríguez JR, Cabeza O, Varela LM (2019) Liquid range of ionic liquid - metal salt mixtures for 
electrochemical applications. J Chem Thermodyn 134:164-174. https://doi.org/10.1016/j.jct.2019.03.012

Salgado J, Villanueva M, Parajó JJ, Fernández J (2013) Long-term thermal stability of five imidazolium ionic liquids. J Chem Thermodyn 65. https://doi.org/10.1016/j.jct.2013.05.049

Sánchez PB, García J, Salgado J, González-Romero E (2016) Studies of volumetric and transport properties of ionic liquid-water mixtures and its viability to be used in absorption systems. ACS Sustain Chem Eng 4. https://doi.org/10.1021/acssuschemeng.6b01541

Sánchez PB, González B, Salgado J, Parajó JJ, Domínguez A (2019) Physical properties of seven deep eutectic solvents based on L-proline or betaine. J Chem Thermodyn 131. https://doi.org/10. 1016/j.jct.2018.12.017

Santos AG, Ribeiro BD, Alviano DS, Coelho MAZ (2014) Toxicity of ionic liquids toward microorganisms interesting to the food industry. RSC Adv 4:37157-37163. https://doi.org/10.1007/ s13595-014-0427-8

Shamshina JL, Rogers RD (2020) Are myths and preconceptions preventing us from applying ionic liquid forms of antiviral medicines to the current health crisis? Int J Mol Sci 21:1-16. https://doi.org/ 10.3390/ijms21176002

Silva FAe, Caban M, Stepnowski P, Coutinho JAP, Ventura SPM (2016) Recovery of ibuprofen from pharmaceutical wastes using ionic liquids. Green Chem 18:3749-3757. https://doi.org/10.1039/ c6gc00261g

Sixto T, Priano E, Reyes O, Parajó JJ, Salgado J, Trasar-Cepeda C (2021) Does soil organic matter affect the impact of the ionic liquid ethylammonium nitrate in the pure state and as mixture with lithium salt on soil basal respiration? Chem Proc 3:1-9. https:// doi.org/10.3390/ecsoc-24-08376

Studzinska S, Buszewski B (2009) Study of toxicity of imidazolium ionic liquids to watercress (Lepidium sativum L.). Anal Bioanal Chem 393:983-990. https://doi.org/10.1007/s00216-008-2523-9

Toledo-Hijo AAC, Maximo GJ, Costa MC, Batista EAC, Meirelles AJA (2016) Applications of ionic liquids in the food and bioproducts industries. ACS Sustain Chem Eng 4:5347-5369. https://doi. org/10.1021/acssuschemeng.6b00560
Ventura SPM, Gonçalves AMM, Sintra T, Pereira JL, Gonçalves F, Coutinho JAP (2013) Designing ionic liquids: the chemical structure role in the toxicity. Ecotoxicology 22:1-12. https://doi.org/ 10.1007/s10646-012-0997-x

Ventura SPM, Silva FAe, Gonçalves AMM, Pereira JL, Gonçalves F, Coutinho JAP (2014) Ecotoxicity analysis of cholinium-based ionic liquids to Vibrio fischeri marine bacteria. Ecotoxicol Environ Saf 102:48-54. https://doi.org/10.1016/j.ecoenv.2014.01.003

Viboud S, Papaiconomou N, Cortesi A, Chatel G, Draye M, Fontvieille D (2012) Correlating the structure and composition of ionic liquids with their toxicity on Vibrio fischeri: a systematic study. J Hazard Mater 215-216:40-48. https://doi.org/10.1016/j.jhazm at.2012.02.019

Wang Y, Wang Z, Sun J, Zheng F, Kotobuki M, Wu T, Zeng K, Lu L (2020) Flexible, stable, fast-ion-conducting composite electrolyte composed of nanostructured Na-super-ion-conductor framework and continuous Poly (ethylene oxide) for all-solid-state Na battery. J Power Sources 454:227949/1-10. https://doi.org/10.1016/j.jpows our.2020.227949

Yang H, Luo X-F, Matsumoto K, Chang JK, Hagiwara R (2020) Physicochemical and electrochemical properties of the (fluorosulfonyl)(trifluoromethylsulfonyl)amide ionic liquid for Na secondary batteries. J Power Sources 470:228406. https://doi.org/10.1016/j. jpowsour.2020.228406

Yasuda T, Kinoshita H, Miran MS, Tsuzuki S, Watanabe M (2013) Comparative study on physicochemical properties of protic ionic liquids based on allylammonium and propylammonium cations. J Chem Eng Data 58:2724-2732. https://doi.org/10.1021/je301284x

Publisher's note Springer Nature remains neutral with regard to jurisdictional claims in published maps and institutional affiliations. 